\title{
Transition to Post-Pandemic Education in the Philippines: Unfolding Insights
}

\author{
Carie Justine Estrellado \\ Tayabas Western Academy \\ Quezon Province, Philippines \\ DOI: 10.29322/IJSRP.11.12.2021.p12074 \\ http://dx.doi.org/10.29322/IJSRP.11.12.2021.p12074
}

\begin{abstract}
This literature review is focused on the rallying cry in the transition to post-pandemic education in the Philippines. The country experienced a series of lockdowns that catapulted prolonged closures of school premises for more than eighteen months and was considered the last country to reopen. As steps to conduct and resume limited in-person classes, selected schools have led the priming for the gradual transition, but the implications of readapting educational landscapes remain an emerging challenge to be dealt with. To delimit the discussion of educational reviews, subtopics were articulated, these are: 1) Integration of Health in Education; 2) Hybrid Learning; 3) Online Learning Space; 4) Assessment and Evaluation Methods; and 5) Enhancing Data Security. This paper reiterates the recalibration of curriculum from the basic and the higher institutions, the campaign for proactive thinking of curriculum planners as well as the underscore of insights that the online and hybrid learning will be mainstay imperative as the country adjusts and awaits the ebbing of the COVID-19.
\end{abstract}

Index Terms- Post-pandemic education, Philippines, transition, insights.

\section{INTRODUCTION}

$\mathrm{A}$ $\mathrm{s}$ the world abates to the disruption of the pandemic, the state of usuality for educational institutions in the Philippines are driven to promote learning through online mediums to help to maintain the flow of education. Schools are challenged to employ distance learning and blended or hybrid learning. These learning modalities suggest adjusting educational technologies in the teaching and learning process. As a result, smartphones and laptops were no longer forms of wants but became necessities. This is because certain technologies are required for students to participate in an online class [5]. Also, schools are accustomed to, and perennial set up of online applications, paired up with online platforms and provide educational materials to support the continuous education of learners and main avenue to communicate with their teachers. But predicaments still are being foreseen, what now the future holds in education?

As the downward trend in the number of COVID positive cases is now evident [46], the Philippine government and educational institutions are eager to grapple with opportunities for the reopening of schools as governments across the world are slowly and steadily easing restrictions. This move has made the education departments hopeful of a safe return of face-to-face classes despite the long school closure [60]. With the yearning to return to the pre-covid instructional form, educational institutions set to integrate health-related activities in their policies and programs this is evident to the issuances of the joint memoranda and guidelines of the Commission on Higher Education (CHED) and Department of Health (DOH) and the DepEd-DOH circular no. 1 series of 2021 of the Department of Education (DepEd) as they commence pilot testing for in-person classes. The DOH encourages education systems to prepare contingency plans, health protocol intervention plans, allocate a budget for the purchase of health equipment and embrace a shared responsibility principle among the stakeholders for the opening of classes. According to the World Bank Group (2020), educational institutions must prioritize post-pandemic initiatives to reduce social and educational disparities arising from months of lockdowns.

\section{Integration of Health in Education}

In the Philippines, they rolled out more vaccines intended for students come November 2021 in their efforts to ensure a safe return of face-to-face classes [29]. This is evident in the collaboration of DepEd and the National Task Force (NTF). For instance, according to Marvin Nicer, the DepEd Division coordinator of Leyte for Disaster Risk Reduction Management (DRRM), when schools are open for face-to-face instruction, only vaccinated teachers will be allowed to interact with the students [10]. However, in Tria's (2020) study, also conducted in the Philippines, vaccination is not necessarily needed for the safe opening of schools. Instead, he said that the wearing of a face mask and the observance of physical distancing is the minimum health requirements. He further states that faculty and staff should strictly follow the established health protocols, such as complying during contact tracing and observance of periodic hand washing. This is in line with Marvin Nicer's statement and Sarmiento et al., (2021) recommendations that schools should ensure physical distancing is maintained and prepare isolation rooms. The Department of Education (2021) advocated the intensification of 
health standards, for instance, the renewed implementation guidelines stated in their sanitation programs found in the DepEd memo 068, series of 2021). It was also announced that when school premises are open, safety and health guidelines must be observed even at the learners' home. Additionally, following the course of the COVID-19 pandemic, local government units, such as that of Baguio City, legislated the inclusion of mental health initiatives directed towards students to improve their overall mental health and capacitate them to better cope with the effects of the pandemic on their mental health [34].

For about two years of experience in the pandemic, several insurgent scholars have studied the challenges and possible rooms for improvement in education. Tria (2020) highlighted in his study that higher education should utilize its research and development to find ways to improve school processes and generate knowledge about the pandemic. This idea of health integration and retrofitting in education and the utilization of the academe in research was discussed by Guingona et al., (2021) in their study on the curriculum formulation, development, and implementation which augment requirements for effectively achieving Universal Health Care. The report addresses two critical issues regarding the integration of health into Philippine education: the adaptation of health curriculum content to local situations and the critical role of research and development in developing improved healthcare. The need to customize the curriculum content of courses, and among other degrees, stems from the notion that health curricula in the Philippines are predominantly western in perspective resulting in detachment from the social realities of local communities. As education strives to localize curriculum content, it should directly reflect on local communities by incorporating local health priorities into learning content, through immersion and internships, and focusing on developing contextualized interventions, since conformity of the health protocols will be the habit to be observed in the schools' culture.

\section{Online Learning Space}

As educational institutions resorted to adopting online learning as a mode of instruction using several learning management systems, the use of smartphones has become further popularized with online learning. Educational institutions in different regions are placed in different situations, but all are considering the possibility of using technology for teaching purposes [3]. Nonetheless, the traditional chalk-to-talk method was replaced by digital learning, resulting in more enhanced learning [39]. The availability and accessibility of information suggest that education should construct a shift from learning transmission to skills development [54]. The online space's emergence for learning brings many advantages for learners. According to Butnaru et al., (2021), the effectiveness of online learning purports to increase learning opportunities via online. Learning with the use of technology allows students to easily access experts, skim and select a wide range of courses or classes, gives them an avenue to join student-based communities, and provides them with an online learning environment. Similar views were found in Santos (2020), where their students said that there are also advantages to learning online. This includes being able to access up-to-date, practically global information with ease.

On the other hand, as online distance education sets the norm, the Philippine setting proves to struggle in the transition to the online learning space. This transition to using digital space as a learning landscape means that the educational system will rely on the Information and Communication Technology (ICT) of the country, which, at present, is described as "not yet fittingly developed, though it is thriving" [37]. Mineo (2021) also noted that not all learners were prepared for the shift in learning modalities. In addition, this transition to an online learning space demands the purchase and proficiency of these resources, such as software, hardware, and other teaching resources, which then requires them to get acquainted with these technologies in order to effectively deliver their roles and for them to physically and adapt to the new learning space $[3,37]$. Thus, this learning setup proved to be difficult for teachers; they especially find it difficult to hold their students' attention for long periods of time. Even instructors were caught unprepared for the paradigm shift $[16,21]$.

Furthermore, the abrupt shift to the online modalities of learning uncovers a significant decrease in course completion and an increased rate of dropouts [28]. Mahyoob's (2020) study revealed that the biggest challenge learners faced were technical issues for instrumental support. Basic actions such as accessing course materials and troubleshooting have been difficult for some, while others find it difficult to join online synchronous classes. Sometimes, learners could not open their exams on their cellular devices. Pastor (2020) found the same findings where key problems mentioned by students were a lack of proper understanding of the lessons, feeling misunderstood by their teachers, and poor or slow internet connectivity. Likewise, Dayagbil et al., (2021) found in their study that technological challenges are usually pinned on low internet connectivity and the inability to afford necessary devices. This goes to show that not all learners have accessibility to capacitate technologies needed for their online learning. One may have acquired a smartphone but could not afford an internet connection. In their study, these differences in accessibility widen the gap and inequalities between students with better access and those that do not have strong connectivity. In general, the lack of technological skills is may cause students to discontinue their education.

These problems have caused emotional and mental distress to students, too. Studies show that students reported having felt high levels of stress and anxiety and a loss of motivation in learning [6, 48, 58]. However, various studies show that the burden and most challenges of online learning fall on the teachers like rethinking and extensive training teaching methodologies for teachers [57]

This publication is licensed under Creative Commons Attribution CC BY.

http://dx.doi.org/10.29322/IJSRP.11.12.2021.p12074

WWW.ijsrp.org 
Consequently, teachers are also challenged to employ different strategies and approaches measures to maintain learners' screen attention and participation [27].

Another problem for teachers is that in cyberspace, as information is widely available, so is misinformation. Teachers are therefore tasked with teaching and training students in information literacy [54]. The Inquirer (2021) suggests that one should check the capacity and well-being of both students and teachers to make flexible learning more accommodating. It is important to make all online interactions as creative as possible to engage students and help them enjoy the online learning space. There is also a trend toward providing students with a more individualized online education experience. Teachers would be able to adapt their teaching methods to address learners' capabilities [4].

Consequently, as the Philippines gradually migrates to the F2F set-up, inferring the turning point of removing the online space is not perceptible since this is usual alternative way to reach students and is relied upon through online means [35]. It is suggested that teachers must be continually engaging upskilling for online and flexible education to adequately plan and implement an appropriate pedagogical program as preparation for the post-covid transition [4]. To which, Joaquin et al., (2020) recommended that the CHED, along with respective Higher Education Institutions (HEIs), encourage initiate future proof steps in attending educators in this transition to the digital learning space, as well as to launch of programs that can augment the identified concerns on connectivity, such as the initiated CHEd Hi-Ed Bayanihan and PHL CHEd CONNECT projects.

\section{Hybrid Learning}

How society works with the presence and effects of the COVID-19 virus is now considered the "new normal". This requires schools to develop different modalities in teaching and learning to accommodate all types of students. The abrupt need for remote teaching has popularized online learning, brought new opportunities to both learners and teachers, and assessed the current educational system [21]. The prevailing modality of instruction as of date is "blended" or "hybrid" learning. The nature of blended and hybrid learning depends entirely on technology, social media applications, and rely on internet connectivity [27]. This is evident for most countries even the developing countries that were plagued by the COVID-19 virus stopped "presential" learning but opted to refocus for blended settings to carry on with their education [5]. It is not just educational institutions but also governments that play an important role in continuing education. Some government agencies have provided avenues for classes to reach students. They broadcast classes via TV for elementary students, while college and graduate students have simultaneously had their online classes either synchronous or asynchronous since the lockdown [21].

For Abbacan-Tuguic (2020), his study presented that some of the students felt comfortable and safe from the virus when they learned from home. It was also found out in her study that students believe that the hybrid learning setup has saved education. PriessBuchheit's (2020) study also indicates that hybrid learning is one of the solutions that could bridge the gap between students with and without internet access.

Synchronous classes through online platforms are also part of hybrid learning. Despite students' positive feedback on hybrid learning as a tool for education in Sahar's (2020) study, they are not satisfied with the kind of learning they receive from their instructors. A study by Pavlidou et al., (2021) also presented that in synchronous classes, learning is stimulated but knowledge sharing is more indepth when it is face-to-face. Still, respondents of the Priess-Buchheit (2020) study said that synchronous classes are sanguine effective over asynchronous classes. It is because it enhances their social competencies, encourages the exchange of multiple ideas, strengthens interactions among participants, provides space for emotional support, provides immediate feedback, supplies verbal elements, and raises student satisfaction. It can be observed that there is different feedback for the different modes of learning.

For Lemay et al., (2021) the administration must realize the disparities among the learners, particularly in the online learning approach. What the pandemic has highlighted is the variations among students in terms of their ability to access the internet for their synchronous classes [54]. In his study, Siegel (2020) suggests that the admin should take note and take careful consideration of the students' time and space available for assignments and activities. Likewise, Hassan (2020) suggests that universities and other educational institutions continue to develop and continue offering online learning. Learning modalities can vary from synchronous classes and recorded video discussions to PowerPoint presentations, screencast and many more. Faculty members are given the privilege to choose to deliver their lessons through online classes to students at home. However, Francisco and Barcelona (2020) believe that learning is more effective if a face-to-face modality is included. According to them, distance learning must be blended with face-to-face learning or flexible learning for the student-professor relationship will be strengthened. They went on to say that this relationship is critical in adjusting to post-pandemic schools.

In the last school year report of 2020, an estimated 3.5 million college students were enrolled in more than 2,400 higher education institutions (HEIs) offering classes during the pandemic [30]. In light of the resumption of classes amid the pandemic, these HEIs have 
initiated their policies and methods to secure the delivery of education despite the COVID-19 restrictions, and among these policies are modified forms of learning.

Pastor (2020) and Mirandilla-Santos (2016) both discussed the highlighted concern of the limited resources available to Filipino students in the transition to blended learning and a highly digital educational landscape. This then led to the introduction of the "flipped classroom" approach, a learning framework, and a variety of blended learning which enables students to study lessons beforehand, which are to be discussed during synchronous meetings [7,41]. While concerns about limited resources, particularly connectivity and gadget access, remain the most pressing among Filipino students, the educational system recognizes the flipped classroom model as alternative means for the current situation, as evidenced by the current state of education that acknowledge the flipped classroom's efficiency in various fields of knowledge [32].

Furthermore, Lapitan et al., (2021) stated that educational institutions themselves initiate methods to augment the recognized challenges of limited resources, and thus reported that the "Discover, Learn, Practice, Collaborate, and Assess (DLPCA)" strategy is one of many strategies developed by schools to address the challenges of resource limitations in the Philippines. In such a method, the aim is to situate educators, learners, and the readily available resources in one landscape for a more customized approach that best fits the social realities of Filipino learners. They expounded in their study that the DLCPA strategy garnered significant advantages for the transition to blended learning by allowing learners to access content materials at their given time of availability, by effectively allowing teachers to incorporate monitoring schemes to track student progress, as well as provide guidance among learners in need of further help, and by efficiently addressing limited access to connectivity. All in all, Lapitan et al., (2021) reiterate that the DLPCA is a worthy method of investment as its benefits outweigh its cost and its potential for adoption for long-term utilization is indeed viable. The pandemic is still a hindrance to the return of the traditional chalkboard mode of setting. However, according to Inquirer (2021), even if an in-person learning set-up is re-introduced, removing technology from their learning process will impair students. The Philippine Daily Inquirer explains that technology is already well-integrated with today's generation because multiple aspects of their lives, including, shopping, hobbies, and self-learning, are connected to cyberspace. This is why implementing new modalities of teaching and learning is important where stakeholders can share their ideas and convenient solutions. Almario \& Austria (2020) suggests that constant dialogue with educators, parents and learners on educational technologies and policies is ideal to serve everyone's best interests.

\section{Assessment and Evaluation Methods}

The reshaping of forms of assessment and evaluation in times of paucity is likewise evident in education, such as deferred grades and extensions of requirements and mass promotion of learners [62], but the report from the Inquirer (2021) has reported that the gap is more pronounced between private and public schools, which have already adapted to blended learning and those that implemented online learning for the first time. The focus has shifted from levelling the opportunities of students instead of as opposed to looking at the entire dimensions of learners' backgrounds [39]. Cahapay (2020) said that with the commencement of hybrid learning, educational institutions adopted several assessment practices like the manner of computation of grades, attendance, availabilities of modalities, and up to giving feedback.

On March 11, 2020, CHED released the COVID Advisory No. 6 series of 2020, giving authority to HEIs to adapt their assessment and evaluation methods, particularly on the timeframe for a subject, degree completion, and perceiving grade weight computations [12]. This was followed by Advisory No. 3, released on March 13, 2020, which provides HEIs the jurisdiction to outline the necessary steps they deem necessary to continue their provision of education. DepEd also released its interim guidelines found in DepEd order number 31 in response to the learning continuum. In response to this, some schools even employ new policies to create a better and equal playing field for students. Some policies ensure that students do not drop subjects in the middle of the school year. Some universities and colleges adopted a "no-fail" policy during the pandemic. However, DepEd's Undersecretary for Curriculum and Instruction opposes this policy because it is more harmful to the students' holistic growth than good [28]. Some schools agree with this idea, so instead, they implemented an emergency policy designed to mitigate the impacts of the pandemic on students' grades and evaluations. This may infer that some universities considering giving passing remarks for enrolled students during the semester [62]. During hybrid learning, it can be noticed that instructors are more lenient with their grading [16]

However, in online assessments, teachers have a limited vent of monitoring students' performance, especially in quizzes. Teachers find it difficult to verify whether students complete their tasks and regulate cheating behavior in online learning platforms [11]. Some teachers utilize online proctors to minimize cheating during online exams. However, Aguilar (2021) stresses that proctoring applications does not necessarily prevent students from cheating. It is also difficult to identify if students are cheating even if suspicious behavior is observed. There are cases where cheating is detected by online proctors. However, proving that there is an intention to cheat will be difficult [53].

For Aguilar et al., (2021), good assessments are those that can help prepare students for future disruptions and uncertainty. The National Academy for Education (2021) also said that assessments should not only measure the outcomes of students' learning (e.g., 
exams and written outputs) but should also check the process of learning. The pandemic brought to the forefront the importance of understanding and documenting the processes and contexts of learning and the need to account for them in the design and interpretation of assessments. Siegel (2020) said that schools, in terms of assessment, should prepare students to enter not only competitive careers but also influence belief systems and associated behavioral expectations. Cahapay (2020) suggests that schools may be proactive in employing a more lenient approach in creating students' assessments during the pandemic while Tria (2020) stated that assessment will continuously redefine as part of the post-pandemic adjustments.

\section{Enhancing Data Security}

Information and data handling are serious concerns during the pandemic. Malindog-Uy (2020) raises the issues of online security and privacy with the advent of online and distance learning in the Philippines. Personal information, such as addresses and phone numbers, is often requested by institutions because of the pandemic. Health and travel history are also some of the personal information obtained by public spaces and organizations due to the pandemic. The issue of data privacy has been overlooked in this pandemic since most of the focus has been given to the development of new teaching modalities [17]. The use of these software tools and other learning platforms that involve a third party raises privacy concerns since educational institutions often ask for students' health information and biometric data online. With the use of smartphones to send personal information, the risk of a data breach is higher [17]. Learners' exposure to the digital world increases their risk of data leakage, identity theft, and other data breach concerns [37].

The National Privacy Commission (NPC) suggests that before using any third-party software, or even those created by the school, it should be scrutinized and explained to parents and students how it will work and what they will do with the private data these students disclose. Specifically, school mandates explain to the parents and students how video recordings taken by audio recorders will be used, who will store them, and what will happen after the course has been finished, and who has the authority to access the video recordings [24]. It is highly suggested that schools only use online platforms that have been developed by schools or the Department of Education to secure students' private information, anchored to the Data Privacy Act of 2012. Furthermore, Dayagbil et al., (2021) mentioned that educational institutions must prioritize data privacy like extending training and orientations for educators to maintain student anonymity, secure the data stored on online platforms, and inform students, parents, and teachers of any threats of data privacy breach.

\section{Conclusion}

The government and educational institutions in the Philippines remain hopeful that the Face-to-face (F2F) classes will be restored in the academe. Both entities have prepared for pilot F2F classes by implementing policies and preparing a budget and contingency plan to mitigate the far-reaching effect of the COVID19. Schools have been active partners with the country's Department of Health in combatting the pandemic as they campaigned for good hygiene and inoculation. Despite the obscurity of the one-size-fits-all strategies and the promise of immediate face-to-face classes, educational institutions and educators are expected to be proactive in the modes of instruction and delivery. Additionally, it is foreseen that hybrid learning will be customary for the education system where teachers are expected to balance the situations of the students having different living conditions and economic backgrounds. Meanwhile, the soundness of assessments and evaluations are also challenged to realign and leverage to the needs of learners wherein teachers are expected to be flexible when dealing with a different mode of instruction. Undeniably, a safe transition back to face-to-face classes needs ample coalescing efforts and consistency among the government, educational institutions, learners, and other stakeholders as the educational landscape continue to adjust through the post-COVID times and while future implications are being sought.

\section{REFERENCES}

[1] Abbacan-Tuguic, L. (2021). Challenges of the New Normal: Students' Attitude, Readiness, and Adaptability to Blended Learning Modality. International Journal of English Literature and Social Sciences, 6(2). https://doi.org/10.22161/ijels

[2] Aguilar, M. G. W. (2021). Academic Dishonesty in the Philippines: The Case of 21st Century Learners and Teachers. International Journal of Management, Technology, and Social Sciences, 6(1), 306-313. https://doi.org/10.47992/ijmts.2581.6012.0146

[3] Alea, L. A., Fabrea, M. F., Roldan, R. D. A., \& Farooqi, A. Z. (2020). Teachers' Covid-19 awareness, distance learning education experiences and perceptions towards institutional readiness and challenges. International Journal of Learning, Teaching and Educational Research, 19(6), 127-144. https://doi.org/10.26803/ijlter.19.6.8

[4] Almario, A. R. \& Austria, R. (2020). Helping K-12 Schools Transition to Post-COVID 19 Times. https://authdocs.deped.gov.ph/wp-content/uploads/2020/06/BELCP-Annex-E-Ani-Almario-Helping-K-12-Schools-Transition-to-Post-COVID.pdf

[5] Avila, E. C., Abin, G. J., Bien, G. A., Acasamoso, D. M., \& Arenque, D. D. (2021). Students' Perception on Online and Distance Learning and their Motivation and Learning Strategies in using Educational Technologies during COVID-19 Pandemic. Journal of Physics: Conference Series, 1933(1). https://doi.org/10.1088/1742-6596/1933/1/012130

[6] Baloran, E. T.. (2020). Knowledge, Attitudes, Anxiety, and Coping Strategies of Students during COVID-19 Pandemic. Journal of Loss and Trauma, 25(8), 635642. https://doi.org/10.1080/15325024.2020.1769300

[7] Bergmann J., \& Sams A. (2012). Flip Your Classroom: Reach Every Student in Every Class Every Day. International Society for Technology in Education. p.20190. 
[8] Betihavas, V., Bridgman, H., Kornhaber, R., \& Cross, M. (2016). The evidence for 'flipping out': a systematic review of the flipped classroom in nursing education. Nurse Educ. Today., 38, p.15-21

[9] Bird, K., Castleman, B., \& Lohner, G. (2021). Negative Impacts From the Shift to Online Learning During the COVID-19 Crisis: Evidence from a Statewide Community College System. EdWorkingPaper No. 20-299 Annenberg Brown University.

[10] Bonachita, B. (2021, October). DepEd helps Leyte schools with pilot in-person class needs. Retrieved from https://www.rappler.com/nation/leyte-schools-facebudget-problems-preparing-pilot-person-classes

[11] Butnaru, G., Nita, V., Anichiti, A., \& Brinza, G. (2021). The Effectiveness of Online Education during Covid 19 Pandemic-A Comparative Analysis between the Perceptions of Academic Students and High School Students from Romania. Sustainability, https://doi.org/10.3390/su13095311.

[12] Cahapay, M. (2020). Reshaping Assessment Practices in a Philippine Teacher Education Institution during the Coronavirus Disease 2019 Crisis. Pedagogical Research (5(4), em0079).

[13] Centers for Disease Control and Prevention. (2021). How Schools Can Support COVID-19 Vaccination. Vaccines and immunizations. https://www.cdc.gov/vaccines/covid-19/planning/school-located-clinics/how-schools-can-support.html

[14] CHED-DOH (2021). Guidelines on the Gradual Reopening of Campuses of Higher Education Institutions for Limited Face-to-Face Classes during the COVID-19 Pandemic. Joint Memorandum Circular No. 2021-001. Retrieved from https://dmas.doh.gov.ph:8083/Rest/GetFile?id=672712

[15] Chiquito, M., Castedo, R., Santos, A.P., López, L.M., \& Alarcón, C. (2020). Flipped classroom in engineering: the influence of gender. Comput. Appl. Eng. Educ., 28(1), p.80-89

[16] Dayagbil FT, Palompon DR, Garcia LL, and Olvido MMJ (2021) Teaching and Learning Continuity Amid and Beyond the Pandemic. Front. Educ. 6:678692. doi: 10.3389/feduc.2021.678692

[17] Dela Rosa, S. (2020, October 23). Report: Distance learning amplifies the need for focus on student data privacy. DIVE BRIEF https://www.k12dive.com/news/report-districts-protect-student-data-privacy-during-pandemic-covid/587616/

[18] Department of Education. (2021, February 24). On the Pilot Implementation of Limited Face-to-Face Classes. https://www.deped.gov.ph/2021/02/24/on-the-pilotimplementation-of-limited-face-to-face-classes/

[19] DepEd-DOH (2021). Operational Guidelines on the Implementation of Limited Face to Face Learning Modality. Joint Memorandum Circular Number 1, series of 2021. https://www.deped.gov.ph/wp-content/uploads/2021/09/DEPED-DOH-JMC-No.-01-s.-2021_.pdf

[20] Department of Education (4 October 2021). Additional Guidelines on the Implementation of DepEd order no. 10, s. 2016. https://www.deped.gov.ph/wpcontent/uploads/2021/10/DM_s2021_068.pdf

[21] Ferri, F., Grifoni, P., \& Guzzo, T.. (2020). Online Learning and Emergency Remote Teaching: Opportunities and Challenges in Emergency Situations. Societies, 10(4), 86. https://doi.org/10.3390/soc10040086

[22] Francisco, C. D., \& Barcelona, M. (2020). Effectiveness of an Online Classroom for Flexible Learning. Online Submission, 4(8), 100-107. https://files.eric.ed.gov/fulltext/ED607990.pdf

[23] Guingona, M. et al., (2021). A Curriculum for Achieving Universal Health Care: A Case Study of Ateneo de Zamboanga University School of Medicine. Front Public Health. https://doi.org/10.3389/fpubh.2021.612035

[24] Halaweh, M. (2021). Are Universities Using the Right Assessment Tools? Higher Learning Research Communications, Volume 11, Issue 0, Pages 1-9. doi: 10.18870/hlrc.v11i0.1184

[25] Hanesby, A. (2011). Globalization: The Global. Retrieved from file://C:/Users/user/Downloads/OByrneHensby2011-Globalization.pdf

[26] Hassan, A. (2020, June). Education Abroad in a Post COVID-19 Pandemic World. Study and Go Abroad. https://www.studyandgoabroad.com/studyabroad/program-types/study-articles/education-abroad-post-covid-19-world/

[27] Heng, K., \& Sol, K. (2020). Online learning during COVID-19: Key Challenges and Suggestions to Enhance Effectiveness. Cambodian Education Forum.

[28] Hernando-Malipot, M. (2021). No fail policy amid the pandemic 'not good' for students - DepEd. Manila Bulletin. https://mb.com.ph/2021/02/01/no-fail-policyamid-the-pandemic-not-good-for-students-deped/

[29] Inquirer. (2021, May). Re-imagining EdTech and the classroom in a post-pandemic era. https://business.inquirer.net/323045/re-imagining-edtech-and-theclassroom-in-a-post-pandemic-era

[30] Joaquin, J.J., Biana , H.T. \& Dacela, M.A. (2020). The Philippine Higher Education Sector in the Time of COVID-19. Front. Educ. https://doi.org/10.3389/feduc.2020.576371

[31] Kerr, B. (2015). The flipped classroom in engineering education: a survey of the research. International Conference on Interactive Collaborative Learning (ICL), pp. 815-818.

[32] Lapitan, L., Jr., Tiangco, C. E., Sumalinog, D., Sabarillo, N. S., \& Diaz, J. M. (2021). An effective blended online teaching and learning strategy during the COVID-19 pandemic. Education for Chemical Engineers, 35, 116-131. https://doi.org/10.1016/j.ece.2021.01.012

[33] Lemay, D., Bazelais, P., \& Doleck, T. (2021). Transition to Online Learning During the COVID-19 Pandemic. Computers in Human Behavior Reports, https://doi.org/10.1016/j.chbr.2021.100130

[34] Lobien, P. (2020). Mental health education inclusion in curriculum urged. Philippine News Agency. https://www.pna.gov.ph/articles/1103248

[35] Lockee, B. B.. (2021). Online education in the post-COVID era. Nature Electronics, 4(1), 5-6. https://doi.org/10.1038/s41928-020-00534-0

[36] Mahyoob, M. (2021). Challenges of e-Learning during the COVID-19 Pandemic Experienced by EFL Learners. Arab World English Journal (AWEJ), Volume 11. Number4 (ISSN: 2229-9327 doi: https://dx.doi.org/10.24093/awej/vol11no4.23), 351 - 362.

[37] Malindog-Uy, A.R. (2020). "Blended Learning" In Virus-Hit Philippines. The ASEAN Post. https://theaseanpost.com/article/blended-learning-virus-hit-philippines

[38] McLaughlin, J.E., Roth M.T., Glatt D.M., Gharkholonarehe N., Davidson C.A., Griffin L.M., Esserman D.A., \& Mumper R.J. (2014). The flipped classroom: a course redesign to foster learning and engagement in a health professions school. Acad. Med., 89, p.236-243

[39] Mineo, M. (2020). Education School Dean Looks at Post-Pandemic Challenges for Schools. Harvard Gazette. https://news.harvard.edu/gazette/story/2021/03/edschool-dean-looks-at-post-pandemic-challenges-for-schools/

[40] Mirandilla-Santos M. (2016). Philippine broadband: a policy brief. Arangkada Philippines-Policy. http://www.investphilippines.info/arangkada/wpcontent/uploads/2016/02/BROADBAND-POLICY-BRIEF-as-printed.pdf

[41] Olakanmi, E.E. (2017). The effects of a flipped classroom model of instruction on students' performance and attitudes towards chemistry. J. Sci. Educ. Tech, 26(1), p.127-137.

[42] Özüdoğru, G. (2021). Problems faced in distance education during the Covid-19 Pandemic. Participatory Educational Research (PER), 8(4), pp. 321-333, http://dx.doi.org/10.17275/per.21.92.8.4 
[43] Pastor C.K.L. (2020). Sentiment analysis on synchronous online delivery of instruction due to extreme community quarantine in the Philippines caused by the Covid-19 pandemic. Asian J. Multi. Stud, 3(1), p.1-6. https://asianjournal.org/online/index.php/ajms/article/view/207/89

[44] Pavlidou, I., Dragicevic, N., \& Tsui , E. (2021). A Multi-Dimensional Hybrid Learning Environment for Business Education: A Knowledge Dynamics Perspective. Sustainability 2021, 13, 3889. https://doi.org/10.3390/su13073889.

[45] Peterson, D.J. (2016). The flipped classroom improves student achievement and course satisfaction in a statistics course: a quasi-experimental study. Teach. Psychol., 43(1), p.10-15.

[46] Philippine News Agency (PNA). (2021, November 25). DOH welcomes a positive outlook on pandemic response. Retrieved November 26, 2021, from https://www.pna.gov.ph/articles/1160852

[47] Priess-Buchheit, J. (2020). Synchronous hybrid learning in times of social distancing: A report and case. International Journal for Innovation Education and Research, $356-364$

[48] Rotas, E., \& Cahapay, M. (2021). From stress to success: Exploring how Filipino students cope with remote learning amid COVID-19 pandemic. Journal of Pedagogical Sociology and Psychology, 3(1), 27-35. https://doi.org/10.33902/JPSP.2021366608

[49] Sahar, N. (2020). COVID-19 Pandemic and Hybrid Learning System. EDUCCON.

[50] Santos, P. (2020). In the Philippines, distance learning reveals the digital divide. Available: https://eu.boell.org/en/2020/10/06/philippines-distancelearningreveals-digital-divide

[51] Sarmiento, P., Sarmiento, C., \& Tolentino, R. (2021). Face-to-face classes during COVID-19: a call for deliberate and well-planned school health protocols in the Philippine context. Journal of public health (Oxford, England), 43(2), e305-e306. https://doi.org/10.1093/pubmed/fdab006

[52] Schleicher, A. (2020). The impact of covid-19 on education insights from education at a glance 2020. https://www.oecd.org/education/the-impact-of-covid-19-oneducation-insights-education-at-a-glance-2020.pdf

[53] Senel, S., \& Senel, H. (2021). Remote Assessment in Higher Education during COVID-19 Pandemic. International Journal of Assessment Tools in Education Vol. 8, No. 2, 181-199.

[54] Siegel, M. (2020, August 11). 5 Major Shifts Needed Post-COVID-19 to Transform Education. Government Technology. https://www.govtech.com/education/k12/five-major-shifts-needed-post-covid-19-to-transform-education.html

[55] Sohrabi, B., \& Traj, H. (2016). Implementing flipped classroom using digital media: a comparison of two demographically different groups perceptions. Comput. Hum. Behav., 60, p.514-524.

[56] Student Privacy Compass. (2020, October 27). Education During a Pandemic: Principles for Student Data Privacy and Equity. https://studentprivacycompass.org/pandemicprinciples/

[57] Talidong, K. J. B., \& Toquero, C. M. D.. (2020). Philippine Teachers' Practices to Deal with Anxiety amid COVID-19. Journal of Loss and Trauma, 25(6-7), 573-579. https://doi.org/10.1080/15325024.2020.1759225

[58] Tria, J. (2020). The COVID-19 Pandemic through the Lens of Education in the Philippines: The New Normal. (1. e.-4. 2020, Ed.) International Journal of Pedagogical Development and Lifelong Learning.

[59] UNESCO. (2021). UNESCO urges all countries to prioritize teachers in national COVID-19 vaccine rollout plans to ensure education can continue safely and schools remain open. UNESCO. https://en.unesco.org/covid19/educationresponse/teacher-vaccination

[60] UNICEF Philippines. (2021, September 21). Reopening schools safely in the Philippines | UNICEF Philippines. https://www.unicef.org/philippines/reopeningschools-safely.

[61] World Bank Group. (2020). Educational policies in the covid-19 pandemic: what can Brazil learn from the rest of the world? World Bank Group Education https://documents1.worldbank.org/curated/en/511671585947801777/Educational-Policies-in-the-COVID-19-Pandemic-What-can-Brazil-Learn-from-the-Rest-ofthe-World.pdf

[62] Yumol, D. T. (2020, April 22). All PLM students to get passing mark amid COVID-19 crisis. CNN Philippines. https://www.cnn.ph/news/2020/4/22/all-plmstudents-get-passing-mark-covid-crisis.html

Correspondence Author - Carie Justine Estrellado, cpestrellado@outlook.up.edu.ph 